\title{
The Research on the Government Industry Guidance Fund Performance Evaluation
}

\author{
Yifei Gong, Kexin Zhang, Qingmei Yuan*, Kaixin Luo \\ College of Economic and Management, Southwest University, Chongqing, China \\ Email: ^836035600@qq.com
}

How to cite this paper: Gong, Y.F., Zhang, K.X., Yuan, Q.M. and Luo, K.X. (2019) The Research on the Government Industry Guidance Fund Performance Evaluation. Modern Economy, 10, 2344-2354. https://doi.org/10.4236/me.2019.1012147

Received: November 11, 2019

Accepted: December 7, 2019

Published: December 10, 2019

Copyright $\odot 2019$ by author(s) and Scientific Research Publishing Inc. This work is licensed under the Creative Commons Attribution International License (CC BY 4.0).

http://creativecommons.org/licenses/by/4.0/

\begin{abstract}
Government-led fund is an effective way to market the financial support and can become an important equity financing channel for emerging industries. At present, the operation mechanism of the domestic government-led fund is not perfect, and the performance evaluation system needs to be established and perfected. The basic principle of government-led fund performance evaluation should be conducive to improving the efficiency of fund operation, guiding the flow of funds to the key areas and weak links of emerging industries, and regulating the behavior of fund management subjects. The performance evaluation system of government-led fund is composed of three major indicators: policy objective, management level and economic benefit.
\end{abstract}

\section{Keywords}

Government Guidance Fund, Performance Evaluation, Evaluation Indicators

\section{The Organization Structure of This Paper}

The first part is to introduce the meaning of the government-led fund and its development process, the second part is to introduce the operation process of the government-led fund, the third part is to point out the existing problems and reasons of the government-led fund, and the fourth part introduces the significance of the performance evaluation of the government-led fund. The fifth part is to construct the performance evaluation system of government industry guidance fund, the sixth part is to design the performance evaluation system of government industry guidance fund, and the seventh part is the government industry fund performance evaluation proposal. The last part is the relevant conclu- 
sions and recommendations.

\section{The Meaning and the Development Process of the Government Industry Guidance Fund}

Governments at all levels shall, through budgetary arrangements, contribute separately or jointly with social capital, adopt market-oriented methods such as equity investment, attract all types of social capital to invest in key areas and weak links of economic and social development, and support funds for the development of relevant industries and fields. The purpose of the establishment is to give full play to the leverage of the financial fund, to promote high-quality capital, projects, talent more to China's entrepreneurial enterprises, emerging industries gathered [1].

The government-led fund has experienced the exploration start, rapid development, standardized operation and other stages. The exploration start-up stage for 2002 to 2006, 2002 China's first government-led fund-Zhongguancun Venture Capital Guide Fund was established [2]. In 2005, the Interim Measures for the Management of Venture Capital Enterprises, which clearly stipulates that "the State and local governments may set up venture capital guidance funds to support the establishment and development of venture capital enterprises", and guided the concept of the fund to be formally put forward for the first time. Until the end of 2006, China has set up a total of six pilot funds, the total size of nearly 4 billion yuan.

The rapid development stage is from 2007 to 2008, statistics show that from 2007 to 2008, the scale of government-led funds close to 20 billion yuan, in October 2008 the Ministry of Finance issued "on the venture capital guidance fund norms and operation of the guidance", clearly defined the concept and connotation of the guiding fund, but also clearly requires the nature of the fund, purpose, establishment, operating principles.

The standardized operation stage is 2009-present, In August 2011, the Ministry of Finance formulated the Interim Measures for the Management of Venture Capital Funds for Emerging Industry Venture Capital Programs, stating that the central financial participation fund should invest in strategic emerging industries such as energy conservation and environmental protection, new energy, new materials, aerospace, etc. From 2009 to 2013, China set up a total of 150 funds, a total size of more than 70 billion yuan.

At present, the government has entered a stable operation period. Statistics show that by the end of December 2015, China had set up a total of 780 government-led funds, amounting to 218.3447 billion yuan. It can be seen that the development and growth of the government-led fund should, to a certain extent, support the development of China's innovative and entrepreneurial enterprises, promote scientific and technological progress, for the adjustment of industrial institutions, the transformation of scientific and technological achievements have played a certain role in promoting. 


\section{The Operation Process of the Government Industry Guidance Fund}

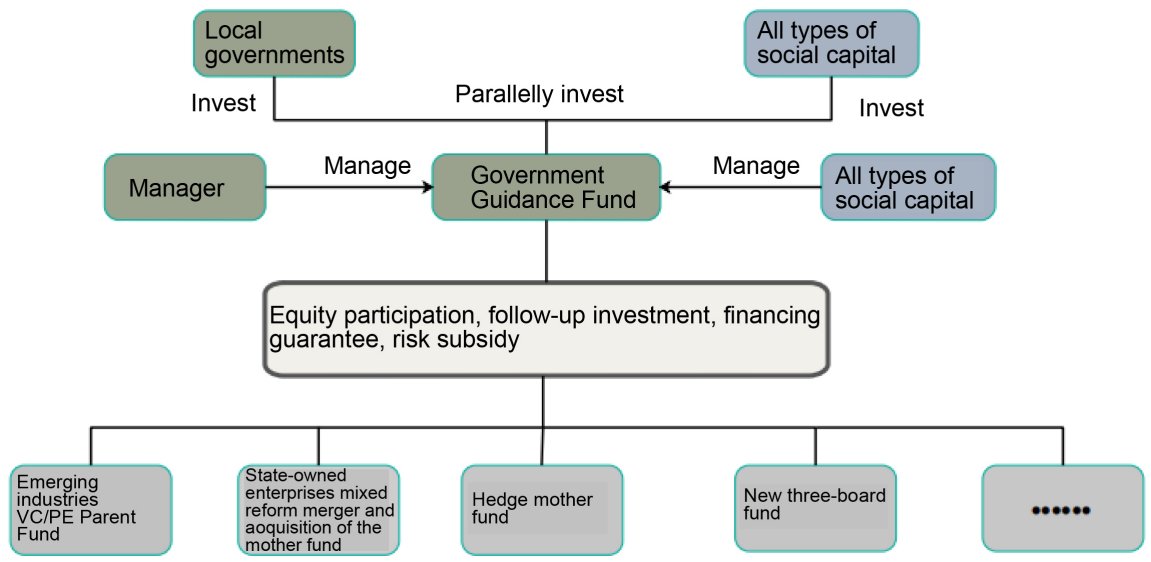

The government's guiding fund is generally set up by the government and related departments to first take out a portion of the funds to set up a special fund, and then the fund as the bottom fund to take equity participation, financing guarantee, follow-up investment or other means to introduce private capital specific operation mode as follows:

\subsection{Equity Participation}

Guide the fund mainly through the way of equity participation, to attract social capital to jointly launch the establishment of venture capital enterprises.

This model is the main mode of operation of government-led funds, that is, government-led funds (often referred to as "mother funds") according to certain criteria to choose qualified, large-scale management, and experienced venture capital firms or private equity, venture fund managers to invest or invest in private equity, A fund product (often referred to as a "sub-fund") set up by a private equity manager of a venture capital. Invest in start-ups through venture capital firms and private equity, venture capital fund managers and their established fund products (sub-funds).

\subsection{Financing Guarantees}

According to the credit report provided by the credit bureau, the venture capital enterprise with good credit record may adopt the form of financing guarantee, which is to make loans to banks and other financial institutions, and raise funds through loan financing.

\subsection{Follow-Up Investment or Other Means}

Industry-oriented guidance fund, through follow-up investment or other means, supports venture capital enterprise development. The mode of operation is the government-led fund to venture capital enterprises to find a better start-up enterprise, at the same time the capital demand is also relatively large premise, can be on the basis of venture capital enterprises to the venture capital enterprises to 
lead investment, investment. Other ways, such as loan risk compensation, the National Science and Technology Achievement Transformation Guide Foundation through loan risk compensation to support the transformation of entrepreneurial enterprises' scientific and technological achievements. Loan risk compensation refers to the conversion loan of the transformation fund to the cooperative bank that meets the prescribed conditions and procedures, and gives certain risk compensation [3].

\section{The Current Problems and Causes of the Government-Led Fund}

\subsection{Low Return, Fund's Return on Investment Is Significantly Lower than Market-Oriented Level}

Compared with market-oriented private equity funds, the return on capital is obviously low. According to Private Equity, the average return of 13,705 private equity funds that have been exited as of March 2018 was 6.48 times, of which 57 government-led industrial investment funds had an average return of just 2.01 times. The level of profit will directly affect the attractiveness of the fund to social capital, and will greatly reduce the financing capacity of industrial investment funds. The main reason is that the Government is directly or indirectly involved in the operation and management of the Fund to a certain extent, resulting in the fund's marketization degree is not high. In 2016, 52\% of the 235 industrial investment funds tested by the National Audit Office were directly designated by government departments and $44 \%$ directly appointed or appointed by the government, and government intervention affected the professionalization of fund management institutions.

\subsection{Less Use, Less High-Quality Projects Result in Idle or Re-Invested Funds}

In recent years, local governments at all levels have set up a large number of government investment funds in a short period of time. However, due to the lack of co-ordination at the time of the establishment of the Fund, it is often the phenomenon that individual projects are supported by multiple funds at the same time, and investments are cross-repeated [4]. Several similar industrial investment funds have been set up in the same region, while relatively few high-quality projects meet the strategic requirements of the fund and market profitability targets, resulting in many funds unable to find projects, resulting in idleness. According to the National Audit Office's survey, 108.251 billion yuan (30\%) of the 13 government investment funds funded by the central government had not been used by the end of 2015; Transferred to commercial bank time deposits, idle phenomenon is prominent.

\subsection{Difficult to Exit, Fund Exit Channel Narrow Limitthes on the Efficient Operation of Funds}

The exit mode of government-led industrial investment funds is relatively nar- 
row, and in the IPO (listing), equity transfer, mergers and acquisitions, liquidation and many other exit options, still mainly IPO. As of March 2018, IPOs accounted for $36.81 \%$ of all private equity exits, with government-led industrial investment funds at 36.84 percent, the highest, according to Private Equity. In practice, China's IPO procedures are more cumbersome, from listing preparation to audit through a long time, often lead to the fund cannot exist in time, and thus limit the efficient operation of funds. The reason for this problem is that the multi-level capital market is not perfect and the fund exit mechanism is not perfect [5].

\section{The Significance of Government-Led Fund Performance Evaluation}

\subsection{Performance Evaluation Is Conducive to Improving the Efficiency of the Fund's Operation}

Market-oriented operation is the key point of the government-led fund different from the general financial expenditure, if the government-led fund operation process, the administrative color is more important, it will reduce the guiding power of social capital. Through performance evaluation, we can examine the operational efficiency of the government-led fund, so as to judge whether the "policy" and "profit-making" objectives have been effectively balanced, and urge the government to take appropriate measures to play the role, so as not to miss, and not to be out of place [6] [7].

\subsection{Performance Evaluation Is Conducive to Guiding Capital Flows to Key Areas and Weak Links in Emerging Industries}

In the selection of indicators, through quantitative indicators to make the use of funds reasonable and centralized can examine the problem of capital investment [8], to avoid the fund investment is too scattered, timely correct the fund investment in the industry, regional imbalance, Avoid inefficient and decentralized investment, thus guiding the real flow of capital to important areas and weak links in emerging industries.

\subsection{Performance Evaluation Is Conducive to Regulating the Behavior of the Main Body of Fund Management}

The main purpose of the government-led fund is to promote social capital to participate in venture capital, the management organization to obtain performance share is not common, resulting in the disadvantage is the lack of effective incentive mechanism. Therefore, through performance evaluation of the fund investment management company and investment team's ability performance appraisal, the behavior of the fund management subject can be regulated.

\section{The Construction of the Performance Evaluation System of the Government Industry Guide Funds}

The design of performance evaluation system of the government industry guid- 
ance fund is different from the commercial investment fund. The guiding fund is a policy fund set up by the government. It does not directly engage in venture capital business, but through equity participation, financing guarantee, follow-up investment or other means to drive social capital into the market failure of venture capital, exerting the leverage amplification effect of financial funds to promote the development of small and medium-sized technology [9]. Therefore, the setting of the guiding fund performance evaluation index system should combine with the compliance evaluation and benefit evaluation.

First, we should pay attention to the "guidance function" of the fund [10], clearly that the funds can be used to focus on encouraging the development of various industries; Second, we must emphasize the leverage effect of the guiding fund. This is the fundamental purpose and requirement of setting up the guiding fund; Thirdly, it is to incorporate economic benefits into the index appraisal system, although the operation of the fund is not for profit, but it is still an investment activity. Whether it has produced economic benefits is also a sign to judge whether its operation is successful or not.

This paper refers to the "Guidance" issued in 2008 and the experts and scholars of the indicator design program, selected Policy objectives, Management effectiveness and Economic benefits to guide the performance evaluation of the fund, shown as the form.

\subsection{Policy Objectives}

The guiding fund is a "policy fund" supporting the development of start-ups. To evaluating the performance of the guiding fund, we must first assess whether to achieve its establishment objectives.

\section{1) Leverage:}

The government funds are bound by the financial budget limited, the important role of the guiding fund is to drive the private capital into the market by guiding the investment of the fund, that is, to produce leverage effect [11]. We use the ratio of the total amount of venture capital led by the fund to the original value of the guiding fund to be a magnification to measure the leverage effect of the guiding fund.

$$
\begin{aligned}
& \text { Proportion of guiding social funds into the scale of venture capital } \\
& =\frac{\text { Fund accumulated amount in place - guiding fund amount }}{\text { guiding fund amount }} \times 100 \%
\end{aligned}
$$

The growth rateof guiding social funds into the scale of venture capital $=\frac{\text { The scale of social funds guided this year }- \text { the scale of social funds guided in the previous year }}{\text { the scale of social funds guided in the previous year }} \times 100 \%$

\section{2) Fund-guided structure:}

High-tech enterprises and start-ups face greater risks and uncertain prospects, commercial investment enterprises are generally unwilling to invest. The government industry guidance fund focus on encouraging the development of strategic emerging industries and improving China's independent innovation capa- 
bilities [12]. We evaluate the investment ratio of the industry-guided fund to the government's key incentives and the ratio of investment in emerging industries or start-ups.

\section{3) Social benefits:}

After supported enterprises in the key industry and regions accepted the guidance fund, whether the independent innovation capability is improved, whether the business performance is improved, the changes in personnel training and introduction indicators, and the employment growth driven can be used to evaluate the social benefits of the industry guidance fund.

\subsection{Management Effectiveness}

Management performance indicators are used to examine the organizational management and capital utilization capabilities of the guiding fund project [13]. It is directly related to whether the fund can continue to develop healthily and steadily.

\section{1) Financial management}

Guided fund's in-place rate focus on measuring whether the guiding fund can be timely and fully in place, which is the premise of investing activities.

$$
\begin{aligned}
& \text { Guided fund's in-place rate } \\
& =\frac{\text { The amount of funds that actual in place }}{\text { The amount of funds that should be in place }} \times 100 \%
\end{aligned}
$$

The financial situation considers the equity structure of the guiding fund, the disputes over the capital contribution, whether the parties have interests bundled, etc.

\section{2) Risk control}

The soundness and effectiveness of internal control is focused on whether the management and operation of the guiding fund have strict investment decision-making procedures and risk control mechanisms, and whether the supervision of funds is in compliance with regulations. The quality of information focuses on measuring the authenticity and disclosure of financial information of the entrusted management department.

\section{3) Governance structure}

The quality and efficiency of the decision-making of the management committee mainly consider the standardization, timeliness and rationality of the decision-making of the management committee. The operation of the management organization includes the degree of mastery of the venture capital enterprise by the management organization and the timely accuracy reported to the management committee.

\section{4) Post-investment management}

The fund's exit management, to check the withdrawal period and exit price of the equity participation from the fund [14], the proportion of successful exit project in the total number of investment projects.

Target completion is to measure the efficiency of the guiding fund, and the 
indicators include the guiding fund annual investment progress and the annual fund average leverage ratio.

The guidin fund annual investment progress

$=\frac{\text { The total amount of funds actually invested in the project that year }}{\text { Fund commitment amount } \div \text { Fund surplus investment period }} \times 100 \%$

The guiding fund annual average leverage

$=\frac{\text { The actual amount of funds actually invested in the current year }}{\text { The actual amount of funds invested by the guiding fund in the current year }} \times 100 \%$

\subsection{Economic Benefits}

The guiding fund attracts a large amount of social capital, although the government usually does not pursue profit in order to play the guiding role and policy objectives, but the financial return is the basic demand of social funders. Therefore, fund performance evaluation should not ignore the evaluation of economic benefits.

1) Investment Income: Mainly measures the profitability of the guided fund.

2) Sustainability: Includes the stability, professionalism, compliance and social evaluation of the investment management team (Table 1).

Table 1. Government industry guidance fund performance evaluation form.

\begin{tabular}{|c|c|c|}
\hline $\begin{array}{c}\text { Level I } \\
\text { indicator }\end{array}$ & $\begin{array}{c}\text { Level } 2 \\
\text { indicators }\end{array}$ & Level 3 indicators \\
\hline \multirow{3}{*}{$\begin{array}{c}\text { Policy } \\
\text { objectives }\end{array}$} & Leverage & $\begin{array}{l}\text { Proportion of guiding social funds into the scale of venture } \\
\text { capital (\%) } \\
\text { The growth rate of guiding social funds into the scale of } \\
\text { venture capital (\%) }\end{array}$ \\
\hline & $\begin{array}{l}\text { Fund-guided } \\
\text { structure }\end{array}$ & $\begin{array}{l}\text { The ratio of the industry-guided fund to the government's } \\
\text { key incentives (\%) } \\
\text { The ratio of investment in emerging industries or } \\
\text { start-ups (\%) }\end{array}$ \\
\hline & Social benefits & $\begin{array}{l}\text { The support effect of the invested enterprise } \\
\text { Employment growth }\end{array}$ \\
\hline \multirow{3}{*}{$\begin{array}{l}\text { Management } \\
\text { effectiveness }\end{array}$} & $\begin{array}{l}\text { Financial } \\
\text { management } \\
\text { Risk control }\end{array}$ & $\begin{array}{l}\text { Fund's in-place rate (\%) } \\
\text { Financial situation } \\
\text { The soundness and effectiveness of internal control } \\
\text { Quality of information }\end{array}$ \\
\hline & $\begin{array}{l}\text { Governance } \\
\text { structure }\end{array}$ & $\begin{array}{l}\text { Quality and efficiency of decision-making by the } \\
\text { Management Committee } \\
\text { Operation of the management organization } \\
\text { Operation of the fund }\end{array}$ \\
\hline & $\begin{array}{c}\text { Post-investment } \\
\text { management }\end{array}$ & $\begin{array}{l}\text { Fund's exit management } \\
\text { Target completion }\end{array}$ \\
\hline $\begin{array}{l}\text { Economic } \\
\text { benefits }\end{array}$ & $\begin{array}{l}\text { Investment } \\
\text { income }\end{array}$ & $\begin{array}{l}\text { Yield } \\
\text { The size of the funds } \\
\text { Management team } \\
\text { Social sustainability }\end{array}$ \\
\hline
\end{tabular}




\section{Recommendations for the Performance Evaluation of Government Industry Guide Funds}

\subsection{Seize the Opportunity of Performance Management, Accelerate the Construction of the Fund Performance Evaluation System}

The performance evaluation of the guiding fund is an important means to measure and manage the economic, efficiency and development of the guiding fund and to reveal the problems existing in the guiding fund. At present, the number of government investment funds is growing, the relevant government departments should make full use of the theoretical and practical experience, demand points of the government and social investors. Reasonably set evaluation indicators, scientifically assign indicator weights. Accelerate the establishment of a scientific, reasonable and efficient performance evaluation index system, to achieve the standardization of government investment fund performance evaluation and the authority of evaluation results.

\subsection{Improve the Legal and Regulatory System, Standardize the Operation of the Fund, Strengthen Risk Control}

The development of China's government-directed funds in the early stage, the laws and regulations are not perfect, which causes various problems in the operation of the fund. Establish a perfect legal and regulatory system, in order to provide a standardized system guarantee for the capital operation and management of the government guidance fund to achieve the healthy development of the fund. At the same time, with the increase of the degree of marketization of the fund [15], the fund management committee should put more energy into the direction of the fund, strengthening risk control, and perfecting the management system, strengthen the supervision of the use of funds, establish a dual disclosure mechanism for information internal and external, prevent financial risks, and ensure the good operation of the guiding funds.

\subsection{Realize the Mechanism of Information Sharing and Optimize the Guiding Fund Coordination Degree}

Under the guidance of policy, governments at all levels have set up investment funds one after another. The repeated evaluation of the same fund not only caused waste of financial funds, but also caused troubles in the daily operation of the fund. In guiding the operation of the fund, encourage government departments at all levels to cooperate with each other, establish information sharing mechanism, set up communication platform, improve supporting services, strengthen the daily dynamic monitoring and post-investment supervision of landing projects in the region, and promote the continuous optimization of fund performance management.

\subsection{Enrich the Source of Funds and Improve Leverage}

Set clear guidelines for fund objectives and investment directions, expand fi- 
nancing channels and the scale of funds, attract and encourage private venture capital institutions to invest in various ways, play the guiding role of guiding fund, improve the efficiency and effectiveness of the use of funds, to solve the financing problem funds for start-ups and emerging industries.

\subsection{Properly Balance the Conflict between Government Funds and Social Funds}

The purpose of the government's guidance fund is to attract social funds to participate in venture capital, and pay more attention to the policy effect of the fund, and social capital investment is to obtain the return of funds. This contradiction runs through the whole process of fund operation. In order to balance policy and economic objectives, a diversified portfolio of investment strategies can be set up. According to the development of local industry, combined with the investment preferences of venture capital institutions, differentiated investment in different fields, stages and regions, not only play a guiding fund policy, but also obtain a better return on investment. Properly balance the conflict between government fund policy and the profitability of social funds, and guide the fund to operate efficiently.

\section{Conclusions and Recommendations}

In recent years, the government's industry guidance fund has achieved good results overall, which has driven private capital and effectively supported the development of enterprises in the initial stage. Based on the "Guidance" and the development of China's guiding funds, this paper elaborates the policy objectives, management efficiency and economic benefits of establishing a complete indicator system, and defines the meaning and evaluation criteria of each indicator, which provides a theoretical basis for further research.

At the same time, in order to further improve the reasonable credibility of the performance management model of the guiding fund, it is necessary to establish a specific operational performance and assessment and supervision mechanism for the guiding funds of local governments. The government industry guidance fund should regularly report relevant data, and the appraisal department regularly publishes performance appraisal results to achieve public supervision of the government guidance fund. Secondly, paying attention to the application of performance evaluation results, the evaluation results should be an important reference for improvement and rewards and punishments. We should seriously analyze the projects with poor performance and poor management, find out the reasons, and truly promote the government industry guidance funds more standardized and efficient.

\section{Acknowledgements}

We acknowledge the social science planning and cultivation project (2016PY42) and the central university basic research business expense project (SWU1909314). 


\section{Conflicts of Interest}

The authors declare no conflicts of interest regarding the publication of this paper.

\section{References}

[1] Liu, G.M. (2016) Government Industrial Investment Fund: Organizational Form, Role Mechanism and Development Performance. Financial Research, No. 9, 34-38.

[2] Liu, N.Y. and Huang, Z.T. (2016) Government Venture Capital Guide Fund Development Analysis. Macroeconomic Management, No. 9, 34-38.

[3] Zhai, J.S., Qian, Y., Hong, L.H. and Huang, Y. (2013) Research on the Operating Mode of the Government Venture Capital Guide Fund. Macroeconomic Management, No. 8, 58-59+76.

[4] Cheng, X.Y. (2013) Government Fund Management Status Status, Existing Problems and Recommendations for Cleaning Up Standards. Price Theory and Practice, No. 7, 31-32.

[5] Xiang, D.W. and Li, Z.Y. (2016) Government Equity Investment Guide Fund: Questions, Analysis and Recommendations. Economic Research Reference, No. 19, 22-27.

[6] Deng, X.L. and Sun, C.P. (2019) Enterprise Innovation, Industrial Upgrading and the Role Mechanism of Government-Led Fund. Journal of Shanxi University of Finance and Economics, 41, 54-67.

[7] Li, H.J. and Bao, X.Y. (2011) Government-Oriented Venture Capital Fund Performance Evaluation Study. Business Research, No. 6, 112-116.

[8] Guo, G.L. (2008) Research on the Related Issues of the Construction of the Performance Evaluation System of China's Industrial Investment Funds. Productivity Research, No. 24, 114-117.

[9] Yang, M.-L., Li, X.-F. and Wu, Y.-H. (2014) Study on the Guiding Effects of the Government Venture Capital Guiding Funds. Science Research Management, 35, 8-16.

[10] Lerner, J. and Watson, B. (2007) The Public Venture Capital Challenge: The Australian Case. SSRN Working Paper.

[11] Gu, J., Ren, P.-J. and Xu, Z.-S. (2015) Study on the Performance Asesment Method of Venture Capital Guide Fund under Intuitionistic Fuzzy Information Environment. Chinese Journal of Management Science, 23, 124-131.

[12] Xiang, Y., Ma, X. and Lu, J.Y. (2018) Study on the Performance Assessment of Government Venture Investment Guidance Fund Based on the Improved IFAHP. Public Finance Research, No. 7, 106-118.

[13] Boyns, N., Cox, M., Spires, R., et al. (2003) Research into the Enterprise Investment Scheme and Venture Capital Trusts: A Report Prepared for Inland Revenue. Mutual Funds, 1-211.

[14] Cumming, D. (2007) Government Policy towards Entrepreneurial Finance: Innovation Investment Funds. Journal of Business Venturing, 22, 193-235. https://doi.org/10.1016/j.jbusvent.2005.12.002

[15] Zhu, Y.-H. and Zhang, M.-X. (2018) Preliminary Research on Efficiency Evaluation of Venture Capital Guidance Fund. Scientific Management Research, 36, 81-84. 